\title{
Engineering Skills and not People through the First-year Design Experience and Service Learning
}

\section{Dr. Jonathan Elliot Gaines, University of South Florida}

Jonathan E. Gaines is faculty in the Mechanical Engineering Department at the University of South Florida. He is the Director of First Year Experiential Education and Learning. Through this position, he develops and implements the curriculum for USF's Foundations of Engineering Lab course. He is also the Principle Investigator for Bulls Engineering Youth Experience (Bulls-EYE Mentoring) a Science, Technology, Engineering, and Math based outreach program that uses undergraduate students to mentor middle school youth. 


\title{
Engineering skills and not people through the first-year design experience and service-learning
}

\begin{abstract}
This Complete Evidence-Based Practice paper draws from the pedagogical theory of servicelearning and how it is used to assess student perceptions of a first-year engineering design course at the University of South Florida. It applies the definition of service-learning by Oakes and Lima [1] as "a pedagogy that integrates service within a local, regional, or global community with academic learning". Also, in accordance with Oakes and Lima [1], the components of the course mirror traditional service-learning experiences in that it possesses four distinct and important components: 1. Service, 2. Academic content, 3. Partnerships and reciprocity, and 4. Reflection. However, course outcomes stop short of service-learning's more ambitious hope- to change students' values and level of civic responsibility. Although increased interest in civic engagement may be worthwhile, logistical challenges for large lecture courses may be minimized by broadening the definition of service-learning to focus on more salient areas of development. In addition, the types of immersive experiences possible on a smaller scale may not be consistently possible in large lecture courses. In spite of these limitations, service-learning in the context of this course may be a useful means to introduce valuable engineering skills. A service-learning course structure developed to achieve engineering skill development is presented along with course evaluation data from the first semester of its implementation.
\end{abstract}

A problem-based course model [2] is used to demonstrate service-learning's potential. Course outcomes aim to provide project management and engineering skills. An evaluation was completed using an adapted form of Gelmon et al. [3] pre- and post- test service-learning survey to better understand student perceptions of the course on 1. Engineering skills, 2. Learning, 3. Aspirations, and 4. Social responsibility. The data suggests that students who completed both the pre- and post- surveys thought the course was a worthwhile endeavor for learning and maintained positive beliefs about their skill development. However, the students' perceptions of the course's potential impact on personal values remained relatively the same. This suggests that the curriculum was effective considering its course outcomes. Ultimately, this paper provides an example for curriculum design and evaluation that may help frame service-learning courses in the future and encourage future research on attitude change in similar contexts.

\section{Background}

In 1979, Robert Sigmon defined service-learning as an educational approach reliant on "reciprocal education" achieved through interactions in the community [4]. Other early uses of the term described service-learning as a learning experience in the community with a formal reflection component [5,6]. Considering these early definitions, there is a beauty in the simplicity of service-learning, i.e., potential for a symbiotic relationship exists to help fulfill the needs of academic learners and local, regional, or global community members. Although these early definitions articulate a simple yet profound foundation for service-learning as an academic 
theory, they in some ways seem limiting when considering contemporary service-learning scholarship. The most glaring difference is in a lack of emphasis on civic engagement or social responsibility. In its applications of service-learning, the field of engineering has mostly acquiesced to contemporary definitions of the academic theory.

Throughout the latter part of the $20^{\text {th }}$ century, substantial academic effort went into better understanding service-learning's potential benefits across disciplines. This history has influenced contemporary scholarship. Kendall et al., [7] discovered 147 different definitions related to service-learning. By the year 2003, Furco had estimated this list had grown to over 200 [8].

Pearson [9] provides a definition with some common characteristics of others. She writes

"The term service-learning was defined in federal legislation for the first time in the National and Community Service Act of 1990 .... [Service-learning is a] method under which students or participants learn and develop through active participation in thoughtfully organized service that:

1. is conducted in and meets the needs of a community, is coordinated with an elementary school, secondary school, institution of higher education, or community service program, and with the community; and helps foster civic responsibility; and

2. is integrated into and enhances the academic curriculum of the students, or the educational components of the community service program in which the participants are enrolled; and provides structured time for the student or participants to reflect on the service experience." $-p g .5$

This definition mentions the components of reflection, cooperation, civic responsibility, and learning. Other definitions focus on service-learning's underlying philosophy for social change. For example, the National Commission on Service Learning (NCSL) [10] defines

"[Service-learning is a] teaching and learning approach that integrates community service with academic study to enrich learning, teach civic responsibility, and strengthen communities" - pg. 9

Although both definitions have the same core components around service and learning there are a few substantial differences. Notably, one claims the discipline helps to foster civic responsibility while the other's expressed purpose is to teach civic responsibility and strengthen communities. The NCSL definition illustrates service-learning's most ambitious hope - that by using an approach based on collaboration and reciprocity with a community member the attitudes and values of both will be changed.

In whole, Programmatic features and characteristics are largely dependent on who is implementing the experience and their priorities [8]. In his article, appropriately titled ServiceLearning: Groping for a Definition, Stanton [11] described two aspects of service-learning saying in many respects, service-learning had become both a pedagogy and a philosophy. This 
duality makes the study of service-learning complex. The challenges inherent with teaching service-learning as a pedagogy may be separate from the challenges of wielding its full and unbridled potential as a philosophy for social change.

In the 1990s there was a heightened interest for service-learning research and evaluation. As practitioners continued to develop service-learning programs, questions about how to best evaluate service-learning experiences became increasingly more important. In their seminal 2001 handbook, Gelmon et al. [4] introduced both quantitative and qualitative methods for capturing essential characteristics. Gelmon wrote about the need to more consistently measure the aspects of service-learning that work towards the realization of productive and positive results. However, providing a more consistent understanding of "what works" has proven to be difficult with traditional research designs and methodologies not able to capture all of the experience's essential aspects [8,12]. Furco [8] defined service-learning along a continuum with other service education programs and artfully defined the continuum as a balance between beneficiary (recipient or provider) and focus (service or learning). In his conclusion, Furco [8] makes an argument for considering a program's intended focuses, beneficiaries, and outcomes when considering service-learning and its potential to be additive in an academic setting. He also makes the case that the process of considering the characteristics of a program might help practitioners better understand where they fall along service-learning's continuum.

It can be argued that service-learning practitioners have not embraced the continuum of servicelearning and thus limited the theory's broader impacts. Outcomes associated with its core philosophy around social justice or increased civic responsibility continue to be very influential if not dominant. These outcomes are tied to service-learning's potential to impact attitudes, values, and beliefs. Practitioners have been able to demonstrate service-learning's worth in this capacity $[13,14,15,16,17]$ with some considering it the most important potential outcome of all $[18,19,20,21]$. When the aim of service-learning becomes just about social justice terms like critical service-learning are used. These values are pervasive throughout the literature and have influenced how service-learning has been applied [22]. For example, in her 2014 book on service-learning and its integration in colleges and universities, O'Grady articulates a belief that traditional academic instruction has little impact on democratic values and her hope that servicelearning can. At the same time, she also acknowledges why service-learning has an inherent challenge with this expectation. Citing two previous studies, O'Grady [22] writes

"Guarasci (1997) believed that through service, students build a "critical experience" in expanded citizenship through having developed "a greater commitment to social interdependence, reciprocity, and a common destiny with all those 'others' who inhabit their immediate social and professional orbits" (p. 22). Smith (1994), however, noted that although civic responsibility or citizenship are frequently mentioned as key service learning outcomes by policymakers and theorists, students themselves rarely describe them as learnings ... unless teachers and those she called "institutional influentials" [sic] do not articulate citizenship as an outcome of service learning and pursue it concretely in the curriculum, students will continue to fail to see the connection" - pgs 9-10 
According to O'Grady, most students seem to not realize outcomes around social responsibility, citizenship, and civic engagement. Two questions might be asked from this quote. Firstly, do practitioners know what it takes to realize these outcomes? Secondly, are these the right outcomes for every situation? There is evidence in the literature that practitioners do not understand how to make the experience "concrete" or what other potential service-learning might have. A third question emerges. Is service-learning "service-learning" if lasting social change is not realized? These questions are relevant to service-learning and the field of engineering

\section{Introduction}

The relevance of service-learning to engineering might best be understood by its relationship to outcomes of accreditation. In many technical fields, including engineering, accrediting bodies do not seek outcomes around a change in attitudes or increased civic engagement at all [23]. This is not to suggest that global citizenship and civic responsibility are not worthwhile endeavors in these fields. But, the outcomes for accreditation reveal priorities for policy makers, practitioners, and institutions [24]. In the field of engineering, the chief accrediting body ABET has released the following list of outcomes [25], none of which allude to programs sparking a shift in student civic engagement, social responsibility, or citizenship. The outcomes do, however, ask for development of skills that are valuable to the discipline. ABET student outcomes are as follows

"[Engineering students should develop]

1. An ability to identify, formulate, and solve engineering problems by applying principles of engineering, science, and mathematics.

2. An ability to apply both analysis and synthesis in the engineering design process, resulting in designs that meet desired needs.

3. An ability to develop and conduct appropriate experimentation, analyze and interpret data, and use engineering judgment to draw conclusions.

4. An ability to communicate effectively with a range of audiences.

5. An ability to recognize ethical and professional responsibilities in engineering situations and make informed judgments, which must consider the impact of engineering solutions in global, economic, environmental, and societal contexts.

6. An ability to recognize the ongoing need for additional knowledge and locate, evaluate, integrate, and apply this knowledge appropriately.

7. An ability to function effectively on teams that establish goals, plan tasks, meet deadlines, and analyze risk and uncertainty."

Outcomes 2, 4, 7 pertain to project and engineering skill development. Outcomes 1 and 3 pertain to learning and applying technical information. Outcomes 5 and 6 allude to personal and community aspirations. But, these aspirations are centered around making better design decisions and not around increased civic engagement. Because no outcomes are present around increasing civic engagement, social responsibility, and citizenship, the philosophy of service-learning put the academic theory slightly in tension with the field. If service-learning is limited to its most narrow contemporary definitions, its ultimate relevance to similar fields may be limited. 
This also does not factor in whether evaluators of service-learning can reliably demonstrate an ability to increase civic engagement and social responsibility in the most relevant circumstances to these fields. This ambiguity in the literature becomes even more pronounced when looking for examples of service-learning as applied to large lecture courses. Many of the documented studies that claim an increase in social responsibility and civic engagement in engineering consider smaller scale, more immersive service-learning experiences or resource intensive, logistically complex ones [26, 27, 28, 29].

In 2018, Gelmon et al. [3] published their long awaited second edition to their 2001 handbook. In the preface they provide a narrative on what has changed since the first edition. They state

"Over the past decade it has become clear that the field was better at creating servicelearning and community engagement programs than it was at assessing, evaluating or even describing them in any systematic way... this leads us to where we are today - a dynamic and exciting era where the focus of this work is now on gathering quality descriptive and analytical evidence about activities. Increasingly this information is used to inform improvement strategies and redesign curricula to enhance community-based learning opportunities." - pg. 13

In other words, curricular design and development of evaluation strategies is an opportunity for the field. This evolution of thought acknowledges the mounting evidence that service-learning works under the right circumstances but questions whether or not we know why it works, how it works best, or the way it should work. For implementations and evaluations, the questions become "how best can we leverage service-learning to achieve relevant learning outcomes for the discipline?" and "what do we gain/give up in realizing the philosophy of service-learning if our outcomes shift towards these priorities?"

\section{Course Structure}

Problem-based service-learning [2] was considered the best service-learning approach for providing engineering students with viable project skills. To develop these skills, students enrolled in the 3-credit hour course outlined in this paper. A total of 540 students took the course during the Fall 2018 term. The course actively focused on project management, engineering skills, engineering design, professional development, and reflection. Like other problem-based service-learning courses, decisions were made in the course design to minimize logistical challenges [2]. The most relevant of these decisions to service-learning is student and community interaction was limited to two design reviews and a final product showcase. Considering the challenge of maintaining valuable reciprocity and cooperation between the community partners and students, the value of collaboration to the engineering design process and the students' professional growth were also points of interest. The class was taught over a 15-week semester, using two 75-minute class periods to deliver course content. 
The 540 students were organized into six sections of 90 students and each section was led by a faculty member from a different department. Sections also were each assigned two student assistants who had previously been trained in delivery of the course content. To ensure reliability between sections the original author of the curriculum served as course director. In this role, he facilitated the project experience for all sections by doing the following

1. The course director taught the first lecture of the week for all sections of the course which was focused on facilitation of the engineering design process, project support, fabrication skills, and engineering communication.

2. The course director used a cloud-based communication platform called Slack to directly communicate with students individually, within their groups, and as a 540 person cohort.

3. The course director coordinated the student assistants during weekly meetings.

4. The course director held a weekly meeting with course faculty.

5. The course director controlled what was uploaded to the learning management system and updated all files and assignments.

The faculty were required to attend the first lecture of the week and observe the course director teaching their students. They then delivered content during the second lecture period of each week. The content delivered by the faculty during the second lecture of the week made connections to the project experience and allowed the students to participate in fun activities that solidified concepts. Although each faculty member was from a different discipline, the course itself was interdisciplinary, meaning each section had a mix of students from all 7 departments in the College of Engineering. Faculty were encouraged to bring their own individual expertise to the table during the second lecture of the week and share their expertise during the weekly planning meetings to enhance the experience for all students.

Student social responsibility was framed through the engineering design process. Engineering was presented as a noble profession that helps other people. Then, the design experience was tied to developing a tool or technology that might be useful for a K-12 STEM education. Students also regularly reflected on the project experience and interactions with the community partner.

In terms of course structure and flow, students metabolized the problem as an individual first and then joined teams of 4-5 where they ultimately adapted an individual role on their team. six project choices were offered to students at the beginning of the semester. During the first week of the course, students chose what design project to complete. Each project choice required students to interact with a community partner during scheduled design reviews.

This structure is executed in three phases. For the first three weeks of the semester students are in the "Individual Design Phase" where they work to metabolize the engineering design problem as an individual before being assigned teammates. At the beginning of Week 4 students begin the "Group Design Phase" where they work through the remainder of the ideation process with their teammates. Lastly, the group enters the "Fabrication Phase" where each group member adopts an individual role on the team and all work towards the fabrication of their project ideas. 
Three community partners were used for the Fall 2018 semester. Partner 1 was an elementary school, Parter 2 was a middle school, and Partner 3 was a non-profit organization. Project types and their descriptions are given in Table 1. Design reviews were collaborative and based on service-learning's central tenet of reciprocity. At the design reviews, each student design team was matched up with at least one elementary or middle school kid. The college students provided the kids with candidate designs to attempt to improve during the design review periods. The elementary and middle school kids provided a unique perspective similarly to how a focus group might operate in a real-world engineering design scenario.

While in the ideation phase, the first design review took place where K-12 kids worked collaboratively with students to develop project ideas. A similar design review took place during the second half of the course when students are working through how to fabricate designs. At the end of the course students complete a project showcase that is structured by the community partner so the partner can share program successes with relevant stakeholders.

There was near uniform distribution of students across all project types with at least $15 \%$ of students being assigned to each project and all students receiving their first choice option.

Table 1: Project types and descriptions offered to students the first week of the course

\begin{tabular}{|c|c|}
\hline $\begin{array}{l}\text { Girl Scouts of West } \\
\text { Central Florida }\end{array}$ & $\begin{array}{l}\text { Students were tasked with creating a web app and curriculum in partnership with Girl } \\
\text { Scouts of West Central Florida. The app was a web app created using the Google App } \\
\text { Maker platform. CAD was required to mock up a STEM badge design upon } \\
\text { completion of the app. The badge curriculum included instructions on how to make the } \\
\text { app, use the app, and/or apply the app to earn an app development STEM badge. }\end{array}$ \\
\hline $\begin{array}{l}\text { Robotics project } \\
\text { Girl Scouts of West } \\
\text { Central Florida }\end{array}$ & $\begin{array}{l}\text { Students were tasked with creating an autonomous robot around the Arduino } \\
\text { microcontroller in partnership with Girl Scouts of West Central Florida. Hardware } \\
\text { components that were needed were an H-bridge for motor control, infrared sensor, and } \\
\text { geared motors. Part of the robot had to be 3D printed. Educational materials had to } \\
\text { include how to make the robot, use the robot, and earn a robotics STEM badge. }\end{array}$ \\
\hline $\begin{array}{l}\text { Microscope project } \\
\text { Mort Elementary } \\
\text { afterschool program }\end{array}$ & $\begin{array}{l}\text { Students were tasked with making a microscope by reversing the direction of the lens } \\
\text { on a webcam in partnership with Mort Elementary School. Students then designed the } \\
\text { microscope's sub-systems which included the stage, lighting, means of adjustment. 3D } \\
\text { printing was also required. Educational materials had to include instructions for } \\
\text { making, using, and integrating the microscope. }\end{array}$ \\
\hline $\begin{array}{l}\text { Speaker project } \\
\text { Mort Elementary } \\
\text { afterschool program }\end{array}$ & $\begin{array}{l}\text { Students were tasked with creating a speaker from an electromagnet in partnership } \\
\text { with Mort Elementary School. They then designed each of the speaker's sub-systems } \\
\text { which included the electromagnet, resonance system, and low-pass filter. 3D printing } \\
\text { was also central to the redesign of one of the speaker's sub-systems. Educational } \\
\text { materials included instructions for making, using, and integrating the speaker. }\end{array}$ \\
\hline $\begin{array}{l}\text { Remote sensing project } \\
\text { Turner-Bartels K-8 } \\
\text { afterschool program }\end{array}$ & $\begin{array}{l}\text { A kite payload was used to carry instruments high into the air for remote sensing in } \\
\text { partnership with Turner-Bartels K-8 school. The kite payload was redesigned for } \\
\text { performance, reliability, and aesthetic value. The project also used measurement } \\
\text { protocols for field testing. Educational materials focused on scientific procedures } \\
\text { making of the kite payload using rapid prototyping, and data acquisition procedures. }\end{array}$ \\
\hline $\begin{array}{l}\text { Fuel cell project } \\
\text { Turner-Bartels K-8 } \\
\text { afterschool program }\end{array}$ & $\begin{array}{l}\text { Students were tasked with creating a toy around a small fuel cell in partnership with } \\
\text { Turner-Bartels K-8 school. Students must leverage the fuel cell to produce mechanical } \\
\text { motion and measure its efficiency. It must rely heavily on the use of CAD. Educational } \\
\text { materials are expected to focus on the math for the efficiency calculation and } \\
\text { instructions on how to make, use, and integrate the fuel cell to into the classroom. }\end{array}$ \\
\hline
\end{tabular}


Table 2 provides an overview of the course structure with weekly deliverables given in the leftmost columns. Generally, the course director would deliver all PowerPoint presentations.

Table 2: Course schedule showing each week, assignments, and activities

\begin{tabular}{|c|c|c|c|}
\hline & Activities and guiding questions & Deliverable \#1 & Deliverable \#2 \\
\hline 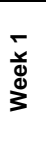 & $\begin{array}{l}\text { Introduction/Overview: Jigsaw 1, design, CAD } \\
\text { Week 1A - Projects and Team Roles.pptx } \\
\text { Week 1B - Design Process.pptx } \\
\text { Week 1C - Jigsaw.pptx }\end{array}$ & $\begin{array}{l}\text { Classwork 1: } \\
\text { Design Process }\end{array}$ & $\begin{array}{l}{ }^{*} \text { Complete pre- } \\
\text { course surveys } \\
\left({ }^{*} \text { not graded) }\right.\end{array}$ \\
\hline 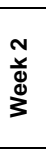 & $\begin{array}{l}\text { Engineering Disciplines/Tools: Jigsaw 2, Functionality } \\
\text { Week 2A - Customer Needs vs Engineering Specifications.pptx } \\
\text { Week 2B - Introduction to TinkerCAD.pptx } \\
\text { Week 2C - Cosmetic vs Functional Design.pptx }\end{array}$ & $\begin{array}{l}\text { Classwork 2: } \\
\text { Engineering } \\
\text { Disciplines }\end{array}$ & CAD 1: Tutorial \\
\hline 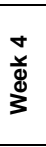 & $\begin{array}{l}\text { Fabrication: Elevator pitch, fabrication, design opportunities } \\
\text { Week 4A - Basics of 3D Printing.pptx } \\
\text { Week 4B - Design Heuristics.pptx } \\
\text { Week 4C - Following Protocols and Procedures.pptx }\end{array}$ & $\begin{array}{l}\text { Classwork 3: } \\
\text { Iterating and } \\
\text { Improving }\end{array}$ & $\begin{array}{c}\text { CAD 2: } \\
\text { Cosmetic design }\end{array}$ \\
\hline 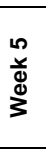 & $\begin{array}{l}\text { Design Review: Engineering skills and strategies } \\
\text { Week 5A - Importance of Reflection.pptx } \\
\text { Week 5B - Weighted Benefit Analysis.pptx } \\
\text { Week 5C - Design Review Expectations.pptx }\end{array}$ & $\begin{array}{l}\text { *Project team } \\
\text { finalization } \\
\left({ }^{*} \text { not graded }\right)\end{array}$ & $\begin{array}{c}\text { CAD 3: } \\
\text { Functional design }\end{array}$ \\
\hline $\begin{array}{l}0 \\
\check{0} \\
\stackrel{\Phi}{3}\end{array}$ & $\begin{array}{l}\text { Leadership: Individual Responsibility and Development } \\
\text { Week 6A - Innovation.pptx } \\
\text { Week 6B - Fabrication Series Overview.pptx } \\
\text { Week 6C - Professional Development.pptx }\end{array}$ & $\begin{array}{l}\text { Professional } \\
\text { Development 1: } \\
\text { Student } \\
\text { Reflection 1 }\end{array}$ & $\begin{array}{c}\text { Design Review 1: } \\
\text { Step 1-4 }\end{array}$ \\
\hline 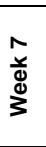 & $\begin{array}{l}\text { Ethics/intellectual property: Jigsaw 3, IP, ethics, prototyping } \\
\text { Week 7A - Memo Writing.pptx } \\
\text { Week 7B - Oral Communication.pptx } \\
\text { Week 7C - Design Review } 3 \text { Expectations.pptx }\end{array}$ & $\begin{array}{l}\text { Classwork 4: } \\
\text { Ethics and } \\
\text { intellectual } \\
\text { property }\end{array}$ & $\begin{array}{l}\text { Teamwork 1: } \\
\text { Fabrication } 1\end{array}$ \\
\hline $\begin{array}{l}\infty \\
\check{\varpi} \\
\stackrel{\Phi}{3}\end{array}$ & $\begin{array}{l}\text { Project } 1 \text { Presentations: Presentations from all groups } \\
\text { Group Presentation Day (casual attire) } \\
\text {-Must submit Memo part } 1 \text { electronically before class begins } \\
\text {-Must submit PowerPoint electronically before class begins }\end{array}$ & $\begin{array}{l}\text { Written Comm. 1: } \\
\text { Memo part } 1\end{array}$ & $\begin{array}{c}\text { Design Review 2: } \\
\text { Presentation }\end{array}$ \\
\hline 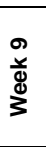 & $\begin{array}{l}\text { Technical skills and manufacture: 3D printing, technical skills } \\
\text { Week 9A - Process Writing.pptx } \\
\text { Week 9B - Curriculum Connections.pptx } \\
\text { Week 9C: Roles Revisited.pptx }\end{array}$ & $\begin{array}{l}\text { Written Comm. 2: } \\
\text { Memo Process } \\
\text { Writing }\end{array}$ & $\begin{array}{l}\text { Design Review 3: } \\
\text { Manufacture }\end{array}$ \\
\hline 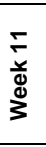 & $\begin{array}{l}\text { Building Progress and roles, realization } \\
\text { Project Work Week (bring hardware to class) } \\
\text {-Student Reflection on the professional development series } \\
\text {-Student Reflection on the project experience }\end{array}$ & $\begin{array}{l}\text { Professional } \\
\text { Development 2: } \\
\text { Student } \\
\text { Reflection }\end{array}$ & $\begin{array}{l}\text { Teamwork 2: } \\
\text { Fabrication } 2\end{array}$ \\
\hline 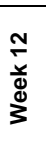 & $\begin{array}{l}\text { Function and reflection: Fabrication, sharing of reflection } \\
\text { Project Work Week (bring hardware to class) } \\
\text {-Student Reflection on individual performance on the team } \\
\text {-Student Reflection on the group's performance }\end{array}$ & $\begin{array}{l}\text { Teamwork 3: } \\
\text { Team Review }\end{array}$ & $\begin{array}{l}\text { *Mulligan } \\
\text { Assignment: } \\
\text { ("not graded) }\end{array}$ \\
\hline 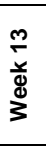 & $\begin{array}{l}\text { Finalizing specifications: Re-design, entrepreneurial mindset } \\
\text { Week 13A - Creating Value.pptx } \\
\text { Week 13B - Final Presentation.pptx } \\
\text { Week 13C - Written Communication Final Paper.pptx }\end{array}$ & $\begin{array}{l}\text { Classwork 5: } \\
\text { Entrepreneurship }\end{array}$ & $\begin{array}{l}\text { Teamwork 4: } \\
\text { Fabrication } 3\end{array}$ \\
\hline $\begin{array}{l}\frac{\sigma}{\sigma} \\
\frac{r}{\Phi} \\
\grave{d}\end{array}$ & $\begin{array}{l}\text { Project showcase and reflection: Discuss/present projects } \\
\text { Project Showcase Week } \\
\text {-Overall Project Reflection } \\
\text {-Service-learning reflection and course evaluations }\end{array}$ & $\begin{array}{l}\text { Showcase: } \\
\text { Final Product } \\
\text { Presentation }\end{array}$ & $\begin{array}{l}\text { Professional } \\
\text { Development 3: } \\
\text { Final Project } \\
\text { Reflection }\end{array}$ \\
\hline \multirow[t]{2}{*}{ 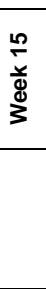 } & $\begin{array}{l}\text { Engineering communication: Reports/communcation } \\
\text { Group Presentation Day (casual attire) } \\
\text {-Must submit Final Report part } 1 \text { electronically before class } \\
\text {-Must submit PowerPoint electronically before class begins }\end{array}$ & $\begin{array}{l}\text { Written Comm 3: } \\
\text { Final Report part } 1\end{array}$ & $\begin{array}{c}\text { Design Review 4: } \\
\text { Presentation }\end{array}$ \\
\hline & $\begin{array}{l}\text { Final Exam: no class } \\
\text {-Submit final paper by due date on Canvas. } \\
\text {-Submit post-course service-learning survey (not graded) } \\
\text {-Submit course evaluation survey (not graded) }\end{array}$ & $\begin{array}{l}\text { Written Comm. 4: } \\
\text { Final Report part } 2\end{array}$ & $\begin{array}{l}\text { Written Comm. 5: } \\
\text { Final Report } \\
\text { Process Writing }\end{array}$ \\
\hline
\end{tabular}


Table 3: Design review schedule for community partner collaboration with purpose

\begin{tabular}{|l|l|l|}
\hline Time & Topic & Description \\
\hline $20 \mathrm{~min}$ & Rapport & Before discussing ideas at all, get to know who is at the table. \\
\hline $10 \mathrm{~min}$ & Motivation & Explain why the design is being built and why we are here. \\
\hline $20 \mathrm{~min}$ & Introduction & Provide technical background information to your audience \\
\hline $20 \mathrm{~min}$ & Presentation & Show and explain group ideas using cosmetic designs \\
\hline $20 \mathrm{~min}$ & Input & Provide time for feedback from the community partner. \\
\hline $10 \mathrm{~min}$ & Reflection & Provide insight into the value of the feedback to what you do next \\
\hline $10 \mathrm{~min}$ & Closing & Map out an action plan \\
\hline
\end{tabular}

A detailed structure of the design review is given in Table 3. Design reviews were held outside of class time during 2-hour periods. Considering there were over 500 students enrolled in the course and each design team had 4-5 people, each project had approximately 20 design teams. Before arriving at a design review, students develop at least two competing ideas to present.

\section{Methods}

This paper presents a first-year engineering curriculum designed to teach project management and engineering design skills using the academic theory of service-learning using a problembased approach. A course evaluation is presented to answer the following evaluation questions

As applied to this course to what degree and in what ways does problem-based service-learning

1. Improve student perceptions of their project management and engineering design skills?

2. Improve student perceptions of their learning in the course?

3. Affect student aspirations in their careers and in their communities?

4. Impact student personal values and potential for future civic engagement?

A total of 540 freshman engineering students enrolled during the Fall 2018 semester with 376 students fully completing the course evaluation. The purpose of the evaluation was to assess the quality of the service-learning experience for the class in relationship to the four evaluation questions. Evaluation questions 1-3 relate back to ABET student outcomes. Evaluation question 4 is related to the philosophy of service-learning. The course design around a problem-based approach was expected to minimize the effect on student perceptions of their values.

An adapted version a pre- and post- test surveys [3] was used to assess evaluation questions 1-4. Both the pre- and post- surveys were administered online. The pre- survey was opened for the first week of classes. The post- survey was open on the last day of class. One point of extra credit was provided to the students for completing both surveys. Both surveys consist of the same 23 questions with pre- test versions worded in the present tense and post- test versions worded in the past tense. Based on the author's perception of the question's intent, each of the questions was categorized based on the evaluation question it addresses. Table 4 provides a summary of the evaluation approach including the evaluation questions for the course, survey questions used to evaluate that aspect of the course and corresponding ABET student outcomes. There is no ABET 
student outcome for Evaluation Question 4 because ABET student outcomes do not cover impact on student personal values and potential for future civic engagement.

Table 4: Summary of course evaluation approach. Evaluation questions of the paper with survey questions of Gelmon [3] in column 1 matched against appropriate ABET outcomes in column 2

\begin{tabular}{|c|c|c|}
\hline \# & Evaluation Questions for the Course & ABET Student Outcomes \\
\hline \multirow{3}{*}{1} & \multirow{3}{*}{$\begin{array}{l}\text { Evaluation Question 1: As applied to this course, to } \\
\text { what degree and in what ways does problem-based } \\
\text { service-learning improve student perceptions of their } \\
\text { project management and engineering design skills? }\end{array}$} & $\begin{array}{l}\text { An ability to apply both analysis and synthesis in the engineering } \\
\text { design process, resulting in designs that meet desired needs. }\end{array}$ \\
\hline & & An ability to communicate effectively with a range of audiences. \\
\hline & & $\begin{array}{l}\text { An ability to function effectively on teams that establish goals, } \\
\text { plan tasks, meet deadlimes, and analyze risk and uncertainty. }\end{array}$ \\
\hline \multirow[b]{2}{*}{2} & \multirow{2}{*}{$\begin{array}{l}\text { Evaluation Question 2: As applied to this course, } \\
\text { to what degree and in what ways does problem- } \\
\text { based service-learning improve student perceptions } \\
\text { of their learning in the course? } \\
\text { Survey Questions: } 1,2,3,4,9 \text {, and } 23\end{array}$} & $\begin{array}{l}\text { An ability to identify, formulate, and solve engineering problems } \\
\text { by applying principles of engineering, science, and mathematics. }\end{array}$ \\
\hline & & $\begin{array}{l}\text { An ability to develop and conduct appropriate experimentation, } \\
\text { analyze and interpret data, and use engineering judgment to } \\
\text { draw conclusions. }\end{array}$ \\
\hline \multirow[t]{2}{*}{3} & \multirow{2}{*}{$\begin{array}{l}\text { Evaluation Question 3: As applied to this course, } \\
\text { to what degree and in what ways does problem- } \\
\text { based service-learning affect student aspirations in } \\
\text { their careers and in their communities } \\
\text { Survey Ques tions/Care er as pirations: } 11,12,13 \\
\text { Survey Questions/Community as pirations: } 6,8\end{array}$} & $\begin{array}{l}\text { An ability to recognize ethical and professional responsibilities in } \\
\text { engineering situations and make informed judgments, which must } \\
\text { consider the impact of engineering solutions in global, economic, } \\
\text { environmental, and societal contexts. }\end{array}$ \\
\hline & & $\begin{array}{l}\text { An ability to recognize the ongoing need for additional } \\
\text { knowledge and locate, evaluate, integrate, and apply this } \\
\text { knowledge appropriately. }\end{array}$ \\
\hline 4 & $\begin{array}{l}\text { Evaluation Question 4: As applied to this course, } \\
\text { to what degree and in what ways does problem- } \\
\text { based service-learning impact student personal values } \\
\text { and potential for future civic engagement } \\
\text { Survey Questions: } 5,7,10,15,18,22\end{array}$ & N/A \\
\hline
\end{tabular}

Questions were assessed using a 5-point Likert scale. A paired two sample t-test was used with an $\alpha=.05$ to compare pre- and post- survey responses for each question. A high average score of 4 or higher was expected for all survey questions pertaining to Evaluation Question 1. A statistically significant increase was expected to be observed for all survey questions that pertain to Evaluation Questions 2 and Evaluation Question 3. No statistical significance was expected to be observed for survey questions corresponding to Evaluation Question 4. The course was expected to increase students' perceptions or maintain already positive beliefs for questions with relationship to ABET student outcomes and have little effect overall on changing student values or interest in civic engagement.

\section{Results and Discussion}

The data for each question and their classification is given in Table 5 including average values for the pre- and post- test, standard deviations (shown using $\sigma$-PRE for pre-test data and $\sigma$-POST for post-test data), and the results from the analysis. SS means statistically significant with arrow 
indicating a statistically significant increase or decrease while HIGH means an average response of 4 or higher on both the pre-test data and the post-test data. The survey questions are given in Table 6 . The questions are also given in Table 6 in their post- test forms.

Table 5: Summary of results for each question along with analysis

\begin{tabular}{|c|l|c|c|r|r|l|}
\hline Q\# & PRE & $\sigma$-PRE & POST & $\sigma$-POST & $\mathrm{P}(\mathrm{T}<=\mathrm{t}), \mathrm{a}=0.05, \mathrm{~N}=376$ \\
\hline 1 & 4.452 & 0.3657 & 4.253 & 0.5200 & $4.151 \mathrm{E}-05$ & $\mathrm{HIGH}, \mathrm{SS} \downarrow$ \\
\hline 2 & 4.104 & 0.5679 & 3.862 & 0.8182 & $4.537 \mathrm{E}-05$ & $\mathrm{SS} \downarrow$ \\
\hline 3 & 2.896 & 0.7065 & 3.601 & 1.0351 & $2.033 \mathrm{E}-23$ & $\mathrm{SS} \uparrow$ \\
\hline 4 & 4.051 & 0.6561 & 4.234 & 0.6917 & $2.001 \mathrm{E}-03$ & $\mathrm{HIGH}, \mathrm{SS} \uparrow$ \\
\hline 5 & 3.048 & 1.3524 & 3.231 & 1.6183 & $4.325 \mathrm{E}-02$ & $\mathrm{SS} \uparrow$ \\
\hline 6 & 4.221 & 0.4391 & 3.737 & 0.9465 & $1.243 \mathrm{E}-14$ & $\mathrm{SS} \downarrow$ \\
\hline 7 & 3.872 & 0.8157 & 4.085 & 0.7501 & $1.007 \mathrm{E}-03$ & $\mathrm{SS} \uparrow$ \\
\hline 8 & 4.130 & 0.5830 & 3.367 & 1.0809 & $1.347 \mathrm{E}-25$ & $\mathrm{SS} \downarrow$ \\
\hline 9 & 4.197 & 0.4785 & 3.928 & 1.0375 & $2.025 \mathrm{E}-05$ & $\mathrm{SS} \downarrow$ \\
\hline 10 & 4.157 & 0.6020 & 4.181 & 0.6339 & $6.789 \mathrm{E}-01$ & $\mathrm{HIGH}$ \\
\hline 11 & 3.593 & 0.9780 & 3.290 & 1.2944 & $8.537 \mathrm{E}-05$ & $\mathrm{SS} \downarrow$ \\
\hline 12 & 3.702 & 0.8550 & 3.301 & 1.1388 & $3.045 \mathrm{E}-08$ & $\mathrm{SS} \downarrow$ \\
\hline 13 & 3.848 & 0.5290 & 3.383 & 0.9089 & $3.004 \mathrm{E}-13$ & $\mathrm{SS} \downarrow$ \\
\hline 14 & 4.335 & 0.4901 & 4.072 & 0.7282 & $8.040 \mathrm{E}-06$ & $\mathrm{HIGH}, \mathrm{SS} \downarrow$ \\
\hline 15 & 4.335 & 0.4901 & 3.785 & 0.6068 & $4.566 \mathrm{E}-29$ & $\mathrm{SS} \downarrow$ \\
\hline 16 & 4.420 & 0.3670 & 4.269 & 0.5597 & $2.119 \mathrm{E}-03$ & $\mathrm{HIGH}, \mathrm{SS} \downarrow$ \\
\hline 17 & 4.364 & 0.4029 & 4.293 & 0.5435 & $1.416 \mathrm{E}-01$ & $\mathrm{HIGH}$ \\
\hline 18 & 4.505 & 0.4000 & 4.553 & 0.4292 & $2.993 \mathrm{E}-01$ & $\mathrm{HIGH}$ \\
\hline 19 & 4.314 & 0.4399 & 4.261 & 0.4226 & $2.686 \mathrm{E}-01$ & $\mathrm{HIGH}$ \\
\hline 20 & 4.380 & 0.3590 & 4.322 & 0.5282 & $2.163 \mathrm{E}-01$ & $\mathrm{HIGH}$ \\
\hline 21 & 4.279 & 0.5005 & 4.194 & 0.5675 & $1.052 \mathrm{E}-01$ & $\mathrm{HIGH}$ \\
\hline 22 & 4.418 & 0.4145 & 4.511 & 0.3359 & $4.072 \mathrm{E}-02$ & $\mathrm{HIGH}, \mathrm{SS} \uparrow$ \\
\hline 23 & $\mathbf{3 . 3 9 6}$ & 0.7359 & 4.511 & 0.3359 & $1.872 \mathrm{E}-63$ & $\mathrm{SS} \uparrow$ \\
\hline
\end{tabular}

\begin{tabular}{|l|}
\hline Description of classification \\
\hline Value to social responsibility \\
\hline Value to engineering skills \\
\hline Value to learning \\
\hline Value to the community \\
\hline Value to personal aspirations \\
\hline
\end{tabular}

Question numbers by classification

Questions 5, 7, 10, 15, 18, 22

Questions 14, 16, 17, 19, 20, 21

Questions 1, 2, 3, 4, 9, 23

Questions 6, 8

Questions 11, 12, 13

Figure 1 graphs the average pre- and post- test data on the value of the experience to social responsibility. Questions 5, 7, 10, 18, and 22 either show a moderate statistically significant increase or high averages in the pre- and post- test. The nature of these questions pertains to general attitudes towards social responsibility and civic engagement. This shows that although the course did not focus on civic engagement student attitudes about engagement in general were not negatively affected. The data for Question 15 which was "The community service involved in this course made me more aware of my own biases and prejudices" shows a statistically significant decrease. One explanation is perhaps students began the course with a positive outlook about enlightenment. But, by the end of the course they did not think the course had the expected effect. For the post test, the evaluation data is not below 3 and the variance is low so there seemed to be few individuals with extreme opinions. It was expected students would leave 
with the values they came into the experience with. The data backs up the assumption made at the onset of the course.

Table 6: Questions on the Gelmon [3] service-learning in the post- test form

\begin{tabular}{|c|l|}
\hline Q\# & Question \\
\hline 1 & The community service aspect of this course helped me to see how the subject matter I learned can be used in everydayl life. \\
\hline 2 & The community service I did through this course helped me to better understand the lectures and readings in this course. \\
\hline 3 & I feel I would have learned less from this course if more time was spent in the classroom instead of in the community. \\
\hline 4 & The idea of combining service in the community with university coursework should be practiced in more classes at this university. \\
\hline 5 & I was already volunteering in my community before taking this service-learning course. \\
\hline 6 & I feel that the community service I did through this course benefited the community. \\
\hline 7 & I probably will volunteer or participate in the community after this course. \\
\hline 8 & The community service involved in this course helped me to become more aware of the needs in my community. \\
\hline 9 & My interactions with the community partner enhanced my learning in this course. \\
\hline 10 & I have a responsibility to serve my community. \\
\hline 11 & Performing service in the community helped me clarify which major I will pursue. \\
\hline 12 & The community service in this course helped me clarify my career plans. \\
\hline 13 & The community service I performed in this class enhanced my relationship with my professor. \\
\hline 14 & The work I accomplished in this course has made me more marketable in my chosen profession when I graduate. \\
\hline 15 & The community service involved in this course made me more aware of my own biases and prejudices. \\
\hline 16 & The service I performed in the community enhanced my ability to communicate in a "real world" setting. \\
\hline 17 & The community service aspect of this course helped me to develop my problem-solving skills. \\
\hline 18 & Most people can make a difference in their community. \\
\hline 19 & This service-learning course helped me become more comfortable working with people different from myself. \\
\hline 20 & The community service I performed in this course helped me learn how to plan and complete a project. \\
\hline 21 & Participating in the community helped me enhance my leadership skills. \\
\hline 22 & I can make a difference in my community. \\
\hline 23 & I would like to enroll in additional service-learning courses at USF. \\
\hline
\end{tabular}

Figure 2 gives the student perceptions of learning. Questions 2 and 9 pertain to the value of the experience to learning. Both showed a statistically significant decrease with relatively high variance. None of the averages in the pre- or post- test are particularly low but certain students may have had a negative experience with community partner interactions. Question 3 was "I feel I would have learned less from this course if more time was spent in the classroom instead of the community" and shows a statistically significant increase. This suggests that more students saw the value of community interactions than not. Questions 4 and 22 suggest that even of a student didn't see the value of service-learning in this class they would try service-learning again. Question 1 was "The community service aspect of this course helped me to see how the subject matter I learned can be used in everyday life" and pertains to application of what they learned. This response was high for the pre- and post- survey results, implying that the students thought what they learned was useful. The result from Question 1 is encouraging for potential positive impact on ABET Student Outcome 2 which reads "[Students should develop] an ability to apply both analysis and synthesis in the engineering design process, resulting in designs that meet desired needs", implying an ability for learned skills to translate to different contexts. 


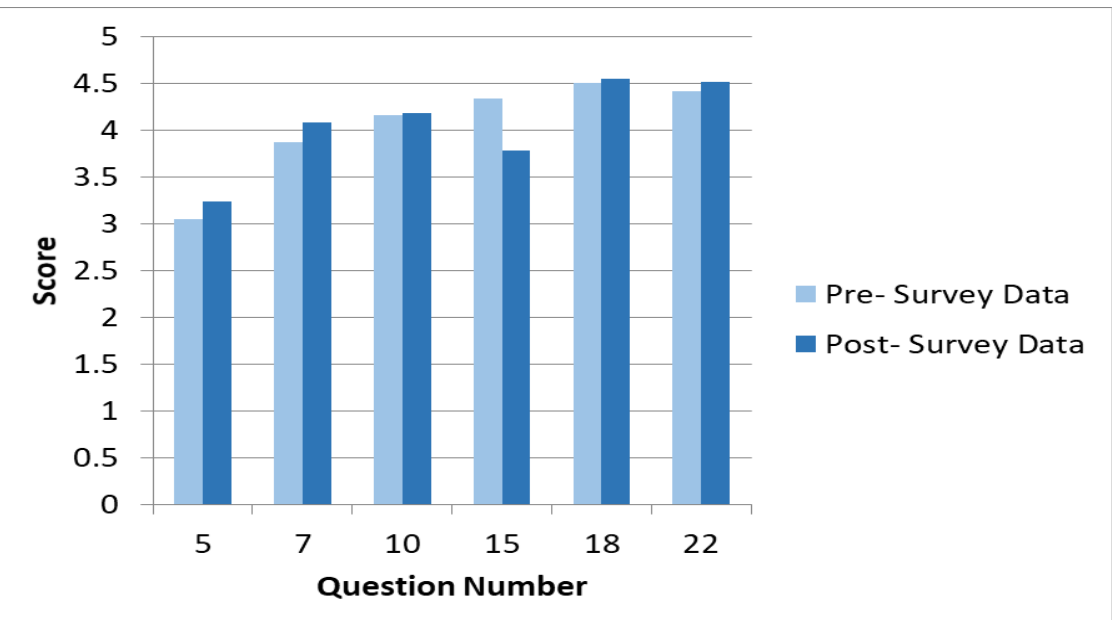

Figure 1: Questions from Gelmon et al. [3] pertaining to social responsibility

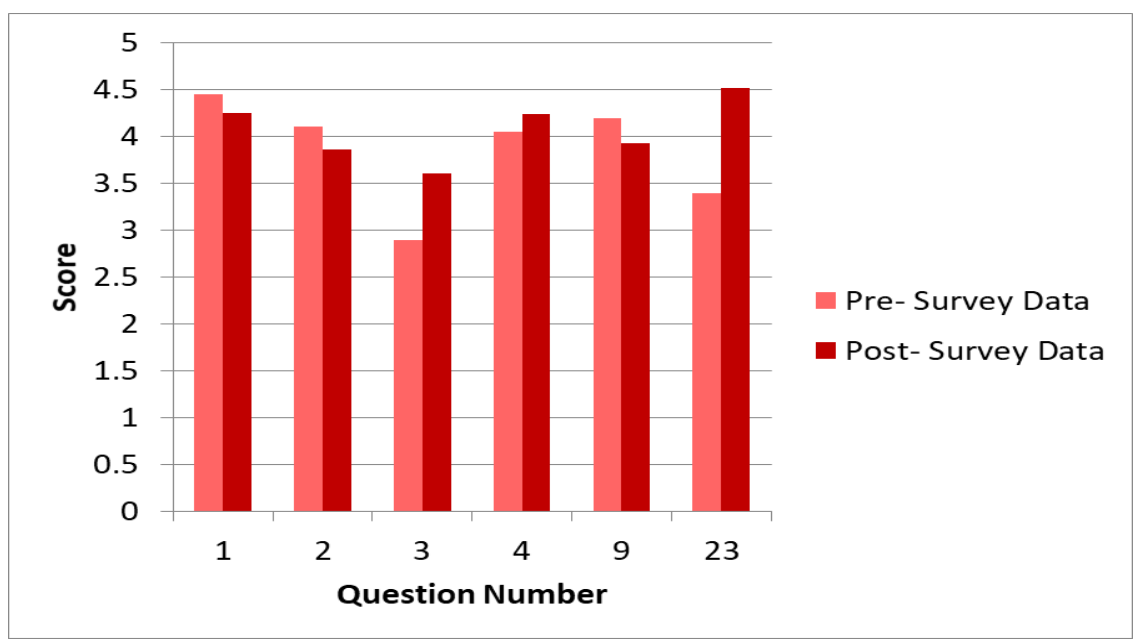

Figure 2: Questions from Gelmon et al. pertaining to learning

Insight on the potential for the course to achieve ABET Student Outcome 1 was the most encouraging. Figure 3 shows that for every question pertaining to project management and engineering skills both the pre- and post- survey results show a high result. This suggests that students had high expectations for the course and its potential to deliver on teaching of engineering skills. And, it also shows students had the perception by the end of the course that the experience delivered on this expectation. Although a high result was observed for all of these questions, Question 14 had the lowest post- test score of this category. Question 14 reads "The work I accomplished in this course has made me more marketable in my chosen profession when I graduate." Because the course is interdisciplinary, students may not have been as satisfied with their project's connection to their discipline. A civil engineering focused project choice as an example was not offered, giving the potential for civil engineering students to be dissatisfied. Question 16 was high for pre- and post- survey results but did exhibit a slight statistically significant decrease. This question was "The service I performed in the community enhanced my ability to communicate in a "real world" setting." This may have been because the design review may not have met some student's expectations for a "real world" environment. 


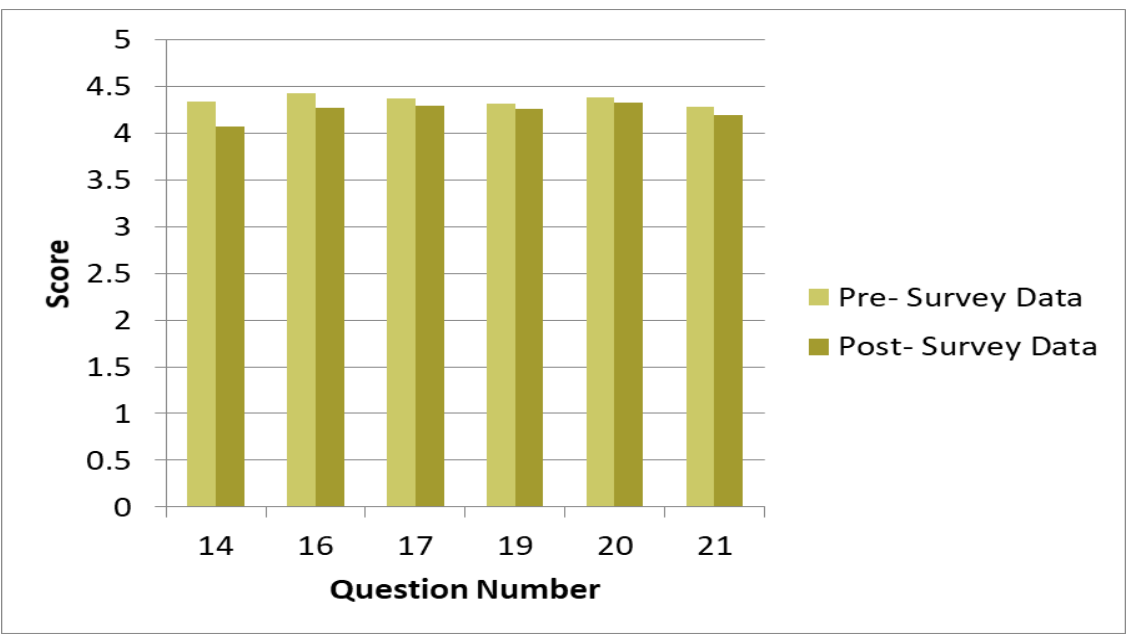

Figure 3: Questions from Gelmon et al. [3] pertaining to engineering skills

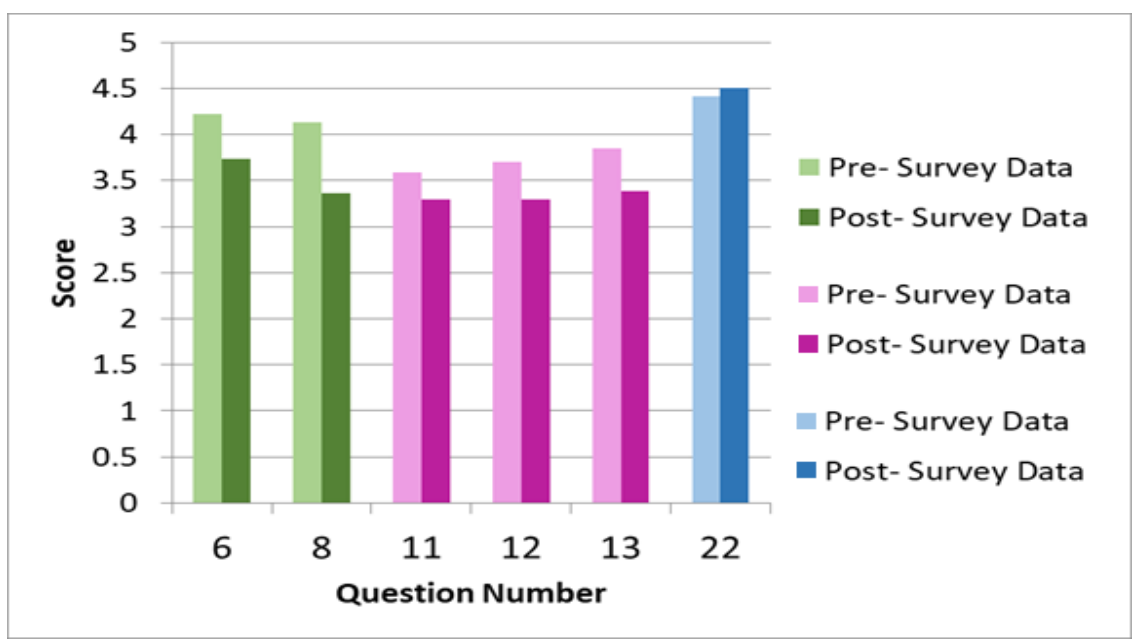

Figure 4: Questions from Gelmon et al. [3] pertaining to community and career aspirations

Figure 4 gives insight into the students' aspirations. Question 11 and Question 12 show students didn't believe the course dramatically impacted their career plans. This might be because many students declare a major before their freshman year. Question 12 was "The community service in this course helped clarify my career plans" and demonstrated a statistically significant decrease. The engineering profession largely requires students to be multifaceted so communication of how project skills translate might provide an opportunity for course improvement. These two questions have some of the highest variances, suggesting there may have been a subset of students with very solidified career plans. Question 6 and 8's averages are above a 4, suggesting students had high expectations for the course to impact the community and help them become more aware of the needs of the community. However, by the end of the course, a statistically significant decrease is observed. One aspect of the service-learning experience that might be sacrificed in the approach detailed in this article is potential to build strong relationships in the community. At the same time, Question 22 is provided again to reemphasize that although students may not have thought this experience made a difference they were not discouraged and in fact remained optimistic that they could make a difference in a different context. 
A course evaluation is presented here so the results are not expected to be generalizable and instead just provide insight into this specific application of service-learning. The results are given as an example for how challenges in the field of service-learning might be addressed. One avenue for the future might be a research study using the ideas presented in this paper. Another avenue for future research is in the potential for the approach taken with the evaluation to lead to a universally accepted way to tie service-learning to ABET student outcomes.

Table 7 is presented here as an example for the types of composites that might be useful when discussing service-learning's relationship to ABET student outcomes. In the table, each question classification type is separated and the scores averaged. For the course presented in this article a few trends are interesting. The category with the highest scores in both pre- and post- test questions is the engineering skills category, suggesting the course was most effective there with the analogous ABET student outcomes being 2, 4, and 7. The six questions pertaining to social responsibility show a pre- and post- test value that is similar, suggesting there may not have been a substantial effect on student perception of increased social responsibility. The classification with the largest difference between pre- and post- test values is the value of service-learning to the community. Because time spent in the community was limited it may indicate what is sacrificed with the outlined approach. Lastly, the personal aspirations classification is generally the lowest. Considering the strong tie this classification has to ABET Student Outcome 3, there may be a need to put more energy into pushing for a higher interdisciplinary emphasis.

Table 7: Composite scores for each classification of questions presented in this paper

\begin{tabular}{|l|c|l|l|}
\hline PRE & POST & Composit of multiple questions & Question classification based on focus \\
\hline 4.056 & 4.058 & Average of questions $5,7,10,15,18,22$ & Value of service-learning experience to social responsibility \\
\hline 4.349 & 4.235 & Average of questions $14,16,17,19,20,21$ & Value of service-learning experience to engineering skills \\
\hline 3.849 & 4.065 & Average of questions $1,2,3,4,9,23$ & Value of service-learning experience to learning \\
\hline 4.176 & 3.552 & Average of questions 6,8 & Value of service-learning experience to the community \\
\hline 3.715 & 3.324 & Average of questions $11,12,13$ & Value of service-learning experience on personal aspirations \\
\hline
\end{tabular}

\section{Conclusion}

The course evaluation presented is for a project-based service-learning approach. As such, the curriculum was structured to provide collaborative experiences with community partners for the expressed interest of achieving ABET student outcomes. Two aspects of this are interesting for the field. Firstly, the course was developed from the start to minimize logistical challenges and focus on engineering skill development. The field is in need of approaches that demonstrate service-learning's potential as a pedagogy and new curricular design. Secondly, the paper presents an evaluation approach that provides insight into the course's characteristics and avenues for future research. One future research area pertains to whether or not it is reasonable to expect a change in student values in a similar context. Another potential research area is related to service-learning's potential to provide engineering skills. Scholars could further investigate what is gained and what is lost in meaningful and concrete course outcomes outside of the context of this course. The example presented here is useful to frame service-learning based on how curriculum could be designed and how evaluation might reveal defining characteristics. 


\section{References}

[1] M. Lima, W. C. Oakes, and J. L. Gruender, Service-learning: Engineering in your community. Great Lakes Press Wildwood, MO, 2006.

[2] K. Heffernan, Fundamentals of service-learning course construction. Campus Compact, Brown University Providence, RI, 2001.

[3] S. B. Gelmon, B. A. Holland, and A. Spring, Assessing service-learning and civic engagement: Principles and techniques. Stylus Publishing, LLC, 2018.

[4] R. Sigmon, "Service-learning: Three principles," Synergist, vol. 8, no. 1, pp. 9-11, 1979.

[5] E. P. Honnet and S. J. Poulsen, Principles of good practice for combining service and learning. Johnson Foundation Racine, Wis., 1989.

[6] J. Luce, J. Anderson, J. Permaul, R. Shumer, T. Stanton, and S. Migliore, "Servicelearning: An annotated bibliography linking public service with the curriculum," 1988.

[7] J. C. Kendall, Combining Service and Learning. A Resource Book for Community and Public Service. Volume II. ERIC, 1990.

[8] A. Furco, "Issues of definition and program diversity in the study of service-learning," Studying service-learning: Innovations in education research methodology, pp. 13-33, 2003.

[9] S. S. Pearson, "Finding Common Ground: Service-Learning and Education Reform. A Survey of 28 Leading School Reform Models.," 2002.

[10] L. Fredericks, E. Holman, and J. Canales, Learning that lasts: How service-learning can become an integral part of schools, states and communities. Education Commission of the States, 2002.

[11] T. Stanton, "Service learning: Groping toward a definition," Combining service and learning: A resource book for community and public service, vol. 1, pp. 65-68, 1990.

[12] N. I. Cruz and D. E. Giles, "Where's the community in service-learning research," Michigan Journal of Community Service Learning, vol. 7, no. 1, pp. 28-34, 2000.

[13] M. Boyle-Baise and J. Langford, "There are children here: Service learning for social justice," Equity \& Excellence in Education, vol. 37, no. 1, pp. 55-66, 2004.

[14] A. Einfeld and D. Collins, "The relationships between service-learning, social justice, multicultural competence, and civic engagement," Journal of College Student Development, vol. 49, no. 2, pp. 95-109, 2008.

[15] T. D. Mitchell, "Traditional vs. critical service-learning: Engaging the literature to differentiate two models.," Michigan Journal of Community Service Learning, vol. 14, no. 2, pp. 50-65, 2008.

[16] Y. Wang and R. Rodgers, "Impact of service-learning and social justice education on college students' cognitive development," NASPA Journal, vol. 43, no. 2, pp. 316-337, 2006.

[17] K. Warren, "Educating students for social justice in service learning," Journal of Experiential Education, vol. 21, no. 3, pp. 134-139, 1998.

[18] J. Saltmarsh, "The Civic Promise of Service Learning.," Liberal education, vol. 91, no. 2, pp. 50-55, 2005.

[19] B. W. Speck and S. L. Hoppe, Service-learning: History, theory, and issues. Greenwood Publishing Group, 2004.

[20] J. Rocheleau, "Theoretical roots of service-learning: Progressive education and the development of citizenship," Service-learning: History, theory, and issues, pp. 3-21, 2004. 
[21] E. Tsang, J. Van Haneghan, B. Johnson, E. J. Newman, and S. Van Eck, “A Report on Service-Learning and Engineering Design: Service-Learning's Effect on Students Learning Engineering Design inIntroduction to Mechanical Engineering,', International Journal of Engineering Education, vol. 17, no. 1, pp. 30-39, 2001.

[22] C. R. O'Grady, "Integrating service learning and multicultural education: An overview," in Integrating service learning and multicultural education in colleges and universities, Routledge, 2014, pp. 17-36.

[23] R. A. Cheville and J. Heywood, "Tensions Between Industry and Academia: Policy Making and Curriculum Development," in The Engineering-Business Nexus, Springer, 2019, pp. 475-498.

[24] B. Ropers-Huilman, L. Carwile, and M. Lima, "Service-learning in engineering: A valuable pedagogy for meeting learning objectives," European Journal of Engineering Education, vol. 30, no. 2, pp. 155-165, 2005.

[25] "Criteria for Accrediting Engineering Programs, 2019 - 2020 | ABET." https://www.abet.org/accreditation/accreditation-criteria/criteria-for-accreditingengineering-programs-2019-2020/ accessed Jan. 29, 2019.

[26] E. J. Coyle, L. H. Jamieson, and W. C. Oakes, "EPICS: Engineering projects in community service," International Journal of Engineering Education, vol. 21, no. 1, pp. 139-150, 2005.

[27] J. Duffy, E. Tsang, and S. Lord, "Service-learning in engineering: What why and how?," age, vol. 5, p. 1, 2000.

[28] A. R. Bielefeldt, K. G. Paterson, and C. W. Swan, "Measuring the value added from service learning in project-based engineering education," International Journal of Engineering Education, vol. 26, no. 3, pp. 535-546, 2010.

[29] E. Tsang, Projects that matter: Concepts and models for service-learning in engineering, vol. 5. Stylus Publishing, LLC., 1999. 